brought to the ground by parachute. The crew have personal parachutes and exit portholes. The balloon itself is three times as large as any previously built. It will contain 3 million cubic feet of hydrogen which will fill it to one tenth of its capacity on the ground. The flight is intended to be of twelve hours' duration, the take off being from a hollow in Black Hills near Rapid City, S.D., when the wind conditions are from the north-west.

\section{Museum of Science and Industry at Newcastle-upon-Tyne}

A notable event for Tyneside, and indeed for the north of England generally, was the opening at Newcastle-upon-Tyne on July 20 of the Municipal Museum of Science and Industry. The ceremony was performed by Mr. R. J. Walker, President of the North East Coast Institution of Engineers and Shipbuilders, which has helped the scheme materially. The gift was accepted on behalf of the citizens by the Lord Mayor of Newcastle, Councillor J. Leadbitter. An institution to record and illustrate the many-sided scientific and industrial advances made in this district had long been talked of, but it was the exhibition held at Newcastle in 1929 which gave impetus to the effort which has culminated in the present Museum. It is housed in a building on the Town Moor, formerly part of that exhibition, and refitted for its present purpose by the Town Moor and Parks Committee of the Corporation. The task of collecting and arranging objects has been in the capable hands of Capt. E. W. Swan, acting with the above Committee. The aim of the Museum is to illustrate development, like the Science Museum, South Kensington, and its scope is similar, but restricted. Excellent progress has been made, in shipbuilding and electricity especially, as might be expected, but a great deal is still to be done. How ever, with the evident enthusiasm, the material available, more adequate funds, and willing helpers, the task should not be too heavy, and we wish the new Museum every success.

\section{Progress in Materia Medica}

In few provinces is it more difficult to define the direction of progress than in the province of materia medica. To eat your enemy's heart that you may add his courage to your own seems a relapse into a barbarism centuries old. Yet medicine has but recently rediscovered that raw liver or the scrapings of the stomach of the pig have a virtue in remedying deficiencies of those organs in man. In 1820, Paris ascribed "the revolutions and vicissitudes which remedies have undergone" to, among other causes, "Superstition, Credulity, Devotion to Established Routine, the assigning to peculiar substances Properties deduced from Experiments made on Inferior Animals, Ambiguity of Nomenclature, the application and misapplication of Chemical Philosophy". As Mr. C. H. Hampshire pointed out in his chairman's address to the British Pharmaceutical Conference at Leeds on July 17, "drugs are introduced on high authority and supported by expressions of clinical confidence, they flourish for a time and then sink into a position of relative unimportance and finally pass almost completely out of use". There is, nevertheless, a point on the circle which represents the best scientific and medical practice of the day, a point which $\mathrm{Mr}$. Hampshire fairly infers to be represented by the "British Pharmacopœia, 1932", a fact which justifies use of that book as a criterion for determining the extent to which the pharmacopoias of other countries reflect what is best in modern medical and pharmaceutical practice.

\section{Modern Pharmacopœias}

Applying the yardstick of the British Pharmacopœia to its contemporaries, he finds the Spanish Pharmacopœia of 1930 one of the most satisfying and instructive of the modern pharmacopœias, although still retaining some aroma of the past by the inclusion of castoreum and musk. The Swiss Pharmacopœia of 1933 is an excellent production pharmaceutically, although omitting modern methods of biological testing, through the absence of a public laboratory for performing these tests in Switzerland, comparable with that of the Pharmaceutical Society in Great Britain: The utility of the Yugoslavian Pharmacopœia, 1934, is limited by its being printed in Slavonian, a difficulty which the Hungarian Pharmacopœia, 1934, overcomes by the use of Latin, the scientific lingua franca of two hundred years ago and still current, though in a bastard form, where physicians and pharmacists work together. The language problem is one only of those disclosed by an examination of eight of the most modern of the European pharmacopœias, and the conclusion to which Mr. Hampshire is drawn is that the steps taken by International Conferences in 1902 and 1925 towards the international unification of the formulæ of potent medicaments should be actively followed up, a proposal which the innocent abroad with his prescription will endorse. His further proposal that there should be a permanent body charged with this duty is probably less likely to be welcomed by a generation grown sceptical of the activities of international committees and disinclined to put its hand in its pocket for the maintenance of yet another.

\section{Future Changes in Medical Practice}

IN addressing the graduates in medicine at the graduation ceremonial at the University of Edinburgh on July 18, Prof. A. J. Clark pointed out that to-day the prevention of disease, or its cure at an early stage, is becoming the chief function of the doctor. It is more interesting to try to enable the human machine to work with full efficiency than to patch up human wreckage so that it can just continue to function, but undoubtedly the diagnosis and treatment of slight deviations from the normal present problems of exceptional difficulty. Another point worthy of notice when considering their future careers, is that the demands of the public will be further modified by inevitable changes in the composition of the population. The figures for the birth rates during the last few years show that the average size of the family in the near future will be nearer 